\title{
Political Identity and Citizenship Participation (Representatives) in Politics by Minangkabau Women in Post-2019 Election
}

\author{
Sri Zul Chairiyah Universitas Andalas, Indonesia
}

\begin{abstract}
This research aimed to describe the identity politics and citizenship of Minangkabau women, towards the political participation (representation) of Minangkabau women in the post-2019 election. Minangkabau women have 2 identities, in adat (matrilineal system) women have rights that are equal to men in decision making, while in religion (patrilineal system), women are not one of the main elements in decision making. In citizenship, community still applies a patriarchal culture that is rooted and dominates. These two identities have a major influence on the political representation of Minangkabau women, where identity politics and citizenship are attempts to understand the relationship of these two concepts to the involvement of Minangkabau women in political representation in each election. The research used aqualitative method with individual analysis. This research was conducted in West Sumatra Province. These two factors influence the political representation of Minangkabau women in West Sumatra. The temporary conclusion showed that the low political representation of Minangkabau women in legislative institutions is not because of identity politics but because of patriarchal culture is still rooted and dominates in the community especially in West Sumatra.
\end{abstract}

Keywords

Citizenship; Identity Politics; Political Participation; 2019 Elections; Political Representative

\section{INTRODUCTION}

The low number of women elected at legislative institutions in Indonesia is still becoming an interesting study by several groups until now, especially by gender activist. This is evidenced by the results of the general election from 2004 to 2019 , the election of women in the legislature shows that the dynamics were still

Sri Zul Chairiyah is a lecturer and professor of political science at the Faculty of Social and Political Sciences, Universitas Andalas, Indonesia. In addition, she was also involved as a researcher and resource person specifically for women and politics, political parties, and elections. Email: srizul.chairiyah@gmail.com.

I am thankful for participants at the 2019 Prodipol International Symposium on Indonesian Politics hosted by Universitas Negeri Semarang-Indonesia for their valuable comments on the early draft of this paper. fluctuating and has not reached a 30\% quota for women's political representation in parliament since the publication of article 65 of Law No. 12 of 2003 concerning affirmative action for women's candidacy in parliament. The election results from these 3 elections can be shown in the table 1.

One of the legislatures in Indonesia that has a problem with the low number of women's choices is the DPRD of West Sumatra Province. This is supported by data in the table 2.

Since the presence of a special government policy for women stated in the 
Table 1. Number of Women in DPR 1999-2009 Election Results

\begin{tabular}{|c|c|c|c|}
\hline $\begin{array}{c}\text { General } \\
\text { Election }\end{array}$ & $\begin{array}{c}\text { The Number of Members } \\
\text { of the Legislature }\end{array}$ & $\begin{array}{c}\text { The Number } \\
\text { of Women }\end{array}$ & Persentage \\
\hline 1999 & 500 & 45 & 9 \\
\hline 2004 & 550 & 65 & 11,82 \\
\hline 2009 & 560 & 100 & 17,86 \\
\hline 2014 & 560 & 97 & 17,32 \\
\hline 2019 & 560 & 118 & 21,07 \\
\hline
\end{tabular}

Election Law on affirmative action, it was first published to be carried out in the 2004 elections until now, in Law No. 12 of 2003 in article 65 paragraph 1 concerning the $30 \%$ quota of women's representation in Parliament, the fact is that the policy has not been able to increase the number of women's electability in the legislature. During the 3 election periods, the number of men was still greater than the number of women. Even the $30 \%$ critical figure for women in the legislature was not achieved.

So far, the maximum number of women's electives in the West Sumatra Provincial DPRD in the 2009 elections amounted to only 7 people out of a total of 55 people. Of course, affirmative action still needs to be improved until it can be used as a solution to increase the women politic representation in legislature. Of the various factors that have not achieved the goal of increasing women in the legislature, a study is needed to dissect this problem. According to Suseno (2010), in understanding the conception of the practice of citizenship, it must be associated with an understanding of the conception of identity. There are differences and similarities between the conceptions of identity and citizenship which cause problems when talking about identity and citizenship (Bernstein, 2005; Maclure, 2003). There are many opinions about identity and citizenship. Scientists agree that both are 'group markers' or group markers. Identity is a distinguishing marker from one group to another, while citizenship becomes a marker of membership in a political community. Although as the same group markers, there are differences between the two, namely the identity of carrying out social culture, and citizenship carrying formal legal burdens (Purvis, 1999).

In this case, the researcher assumes the low representation of Minangkabau women in the legislature due to the still strong patriarchal culture in the context of citizenship in Indonesia, whereas women in Minangkabau society have 2 identities, in adat (matrilineal system applies) women have equal rights with men in decision making, while in religion (patrilineal system 
Table 2. Comparison of election results, 2009 and 2019 in Women's Representation in the West Sumatra Provincial Regional People's Representative Assembly

\begin{tabular}{|c|c|c|c|}
\hline No. & Political Party & 2009 & 2019 \\
\hline 1 & Demokrat & 3 & - \\
\hline 2 & Golkar & 1 & 1 \\
\hline 3 & PDIP & $\begin{array}{ll}- & \\
-1\end{array}$ & 1 \\
\hline 4 & PKS & - & - \\
\hline 5 & PAN & 2 & - \\
\hline 6 & PBB & - & ---- \\
\hline 7 & PPP & - & ---- \\
\hline 8 & Gerindra & 1 & 2 \\
\hline 9 & Hanura & $\begin{array}{lll}- & \\
-1\end{array}$ & $\begin{array}{lll}- & \\
-1\end{array}$ \\
\hline 10 & Nasdem & - & - \\
\hline & $\begin{array}{c}\text { The Number of Women Legislatve } \\
\text { Members Elected }\end{array}$ & $\begin{array}{c}7(55) \\
(12,72 \%)\end{array}$ & $\begin{array}{c}4(65) \\
(6,15 \%)\end{array}$ \\
\hline
\end{tabular}

applies), the political context of identity in Minangkabau society, the prevailing culture is precisely cultural patrilineal (Sait, 2013).

Regarding the description described above it is very interesting to see how the political representation and the political tendency of identity and citizenship to the political representation of Minangkabau women viewed in the 2019 legislative elections held today.

This study used some relevant previous research that served to assist the writer in conducting academic studies related to the problem that the author was doing. Previous research that is relevant to this research is research conducted by Idris (2010), entitled "Minangkabau Women in Politics". Nurwani's research examined Minangkabau women in politics that were egalitarian and had a central character in the society.
In Minangkabau society, there is a sharp gap between women's representation and equality. In general, the representation of women in politics and local political position in West Sumatra is still low. In fact, there is no causal relationship between women's egalitarian characteristics and their position in politics. In fact, egalitarian characteristics do not have a significant effect on elections. This is clearly seen in the recruitment and voting system, a regulation that provides more opportunities for women in their efforts to reach elected posts. To succeed in politics, they must have a high interest in politics and make optimal, progressive and sustainable efforts. The second study, research from Lidya Victorya Pandiangan, (Pandiangan, 2017), entitled Women Minangkabau Politicians in the World of Politics: Study of the Reasons Women Mean Politics. This research tried to 
explore the reasons for women to be involved and involved in politics when they lived and were in the midst of matrilineal culture. The results of this study indicated that there were 3 reasons for political meanings for women in Minangkabau. First, that women politicians interpreted politics as synonymous with power, where as a woman must be brave to gain power, because the power in the hands of women is actually better than the power in the hands of men (Elfira, 2018). Second, their meaning and understanding of politics were more influenced by their experience in social/political organizations, professions or work experience. Third, there was the contribution of matrilineal culture to women politicians. In contrast to the above research, the author wants to obtain a picture of the political representation of Minangkabau women in the legislature by using the concepts of identity and citizenship politics.

\section{RESEARCH METHOD}

The design of this study is a qualitative method involving several research participants as key informants. The research participants who acted as participants were selected by purposive sampling method, namely participants selected based on certain criteria. The settings and instruments of this study were conducted in the West Sumatra region with a total sample of 10 bundo (elite woman politicians) informants as members of the legislature. The research instruments used were: image and sound recording equipment, writing equipment, and complementary purposes. For the questions submitted to participants, interview guidelines would be prepared for in-depth interviews. In addition to interviews, data collection was done with secondary data.

This study also used the literature study method as a way to conduct an analysis so that results that can be scientifically justified were obtained. An argument needs to be supported with data and scientific studies so that it can be accounted for. For this reason, this research also used the literature study to support the argumentation that was built.

This research was intended to obtain a description of Minangkabau women in relation to political participation in political representation in the legislative institution in the perspective of identity and citizenship politics.

\section{LITERATURE REVIEW}

Overall, relevant research that can be used as a reference for this article is research from Nasrudin and Nurdin (2018), with the title "Political Identity and Political Representation" (Case Study in the 2018-2022 DKI Election Period). This 
study examined the concept of identity politics specifically about religion and culture that is associated with political representation. This is to analyze the democratic process in Indonesia. The study was conducted using qualitative methods (Moleong, 2004). The results of the study showed that the political orientation of identity and political representation influenced the democratic process in the case of the 2018-2022 DKI Regional Election.

The next reference is from Muhtar Haboddin research entitled "Strengthening Identity Politics in Local Politics" (Haboddin, 2012). In the abstract it is explained that the strengthening of identity politics at the local level coincides with the politics of decentralization. After the stipulation of Law No. 22/1999, the identity politics movement is increasingly clear. In fact, many actors both local and national politics used this issue intensely for power sharing. This research used literature study as the analysis. Identity politics occurring in Riau, Central Kalimantan, West Kalimantan and Irian Jaya which were the focus of the study in this article, showed the strength of this issue (Snanfi et al., 2018). This issue was used by political actors when negotiating with other political entities.

Ardiansa (2017), the researcher from the Center for the Study of Political
Science of the Social and Political Sciences Faculty, University of Indonesia, in the context of the practice of political representation in Indonesia and its relation to the issue of women's political representation, he viewed that the practice of women's political representation in Indonesia in these three discourses, namely (1) political representation will not present a perfect representation of interests and identity, (2) democratic political representation occurs if those whose interests are influenced or touched by a decision have the capacity to (engage) influence the decision making, (3) political representation can be generated from electoral (electoral) and non-electoral processes, and offers ideas and recommendations for efforts to increase the representation of women as well as efforts to present women's interests (Samry \& Omar, 2012). This study views the practice of women's political representation in Indonesia in the three discourses, and offers ideas and recommendations for efforts to increase the representation of women as well as efforts to present women's interests.

Suseno (2010), said that Citizenship became a major theme and issue in politics after competition between the Western bloc (liberalism/capitalism) and the Eastern bloc (socialism/communism) ended with the collapse of Communist 
regimes in Eastern European countries. The first reference shows that the political Citizenship is a concern of feminist orientation of identity and political political theorists who are critically studied representation influence the democratic and proposed as alternatives to the process in the 2018-2022 DKI Regional conception of mainstream citizenship. The Election case. A reference from Haboddin latest discourse on female citizenship (2012), the strengthening of identity refers to a gender-oriented citizenship politics at the local level coincided with a model. These changes have an impact on policy of decentralization after the policies for citizens in various countries. stipulation of Law No. 22/1999. This article discusses the possible Meanwhile, Ardiansa (2017), his study of conception of citizenship in a feminist women's political representation in the perspective that can be used to context of the practice of political understand the problems and challenges representation in Indonesia and its relation faced by women in Indonesia today.

to the issue of women's political

Furthermore, Suseno (2011) said that citizenship policies that are friendly to women need to be implemented if women are involved in the practice of citizenship. This policy is not solely based on the conception of universal mainstream citizenship, but which can synthesize the dimensions of similarities and differences within the framework of Gender pluralism. In this conception of citizenship, the maintenance dimension needs to be incorporated into the practice of citizenship. To realize this conception in practice, the separation between private and public as a mechanism for the exclusion of women from the public sphere is no longer acceptable.

From the description several studies described above, there are differences between this article and previous studies.

\section{RESULTS AND DISCUSSION Citizenship as a Membership}

The membership dimension emphasizes that citizenship is based on a distinction between those inside and outside the community. The nation-state citizenship model accommodates various 


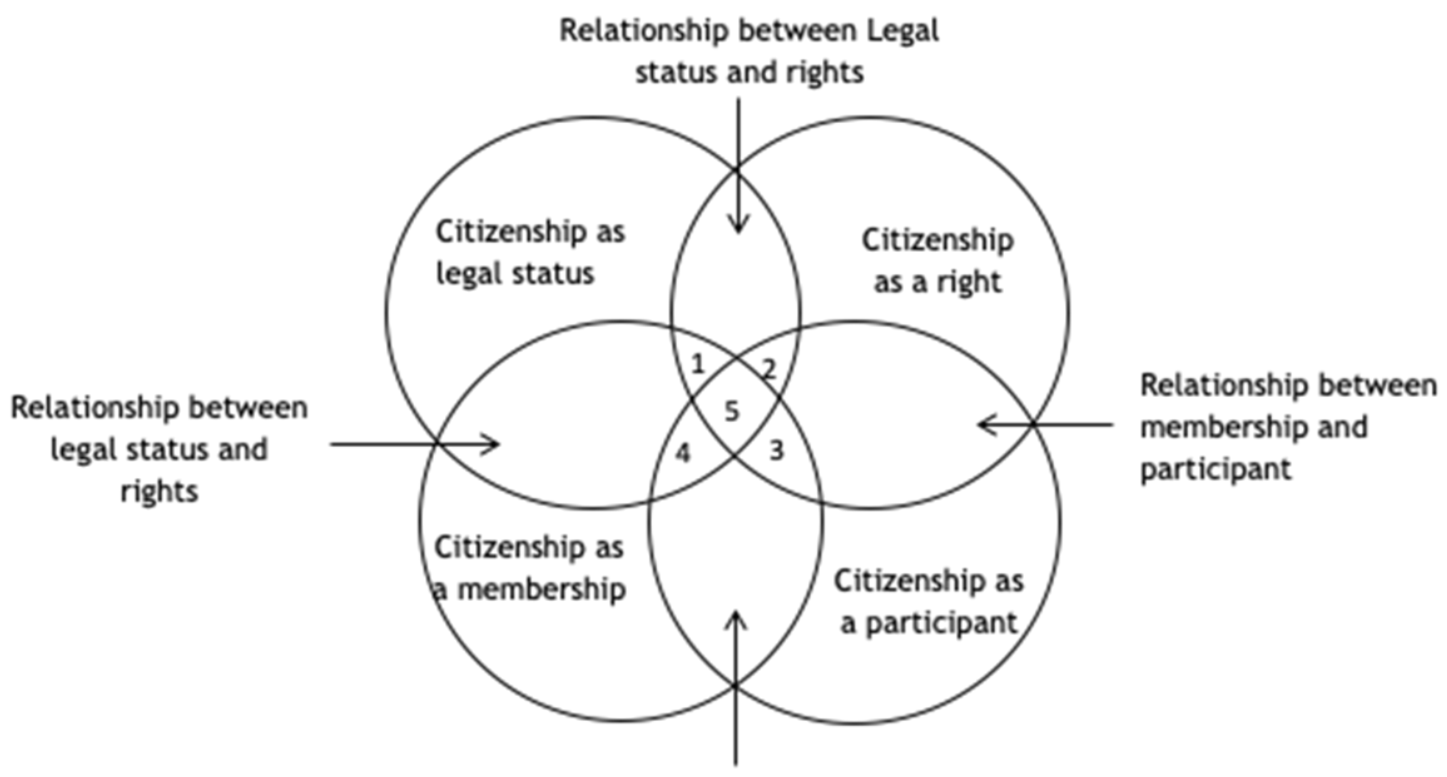

The relationship between membership and participation

Figure 1. Dimensions of Citizenship (Hiariej and Stokke, 2018).

Stratified Citizenship:

1. Membership, legal status and rights without participation (citizens are politically excluded)

2. Legal status, rights and participation without membership (citizens are culturally excluded)

3. Membership, rights, participation without legal status (residents are legally excluded)

4. Membership, legal status, rights and participation (full citizens)

The meaning of citizenship politics by giving attention to three dimensions:

1. Political recognition (Citizenship as membership)

2. Politics of Redistribution (Citizenship as social rights)

3. Politics of Representation (Citizenship as political participation

contextual variations in the formation of nationalism.

\section{Citizenship as Legal Status}

Based on membership in a community of nations, the state applies citizenship as a legal status, which means that there is a contractual relationship, which gives rise to rights and obligations, between individuals and the state. Complexity in the various principles of being a citizen is reflected in the complexity and diversity of experiences of being a citizen.

\section{Citizenship as Rights}

The third component of citizenship is a set of rights relating to the status of membership and formal citizenship. General categorization initiated by Marshall and Bottomore (1992) includes three types of rights: civil, political, and social. Key lessons from this debate about social rights are involved. This applies to various struggles over civil and political rights in the context of authoritarian regimes and also the struggle for social rights in the context of liberal democracy. 
Citizenship as Participation

The main meaning of citizen participation is involvement in governance of public affairs. This political obligation is the main theme in the citizenship approach. Thus, citizenship has intrinsic links with politics and democratic theory as a way to guarantee political control by citizens. Representation is based on the idea of a widespread democratic chain of rights-holders and elected representatives towards democratic governance of public affairs.

In this case, based on the chart above, the citizenship of Minangkabau women is stratified in point number 2 , namely legal status, rights and participation. without membership (citizens outside the culture). Based on the citizenship diagram that the status of Minangkabau women both legally, rights and participation have fulfilled, but as citizens in the context of formal legal applies patriarchic culture

\section{Politics of Identity}

Theoretically, identity politics is political to prioritize the interests of members of a group because they have the same identity or characteristics, whether based on race, ethnicity, gender, or religion (Nasrudin and Nurdin, 2018; Kristianus, 2016). Identity politics as a sign of political activity. Meanwhile, in a broader sense, identity politics is concerned with liberation from marginalized situations that specifically include the constituency (membership) of groups in a broader context or biological goals from a point of view.

Therefore, in the general theory of identity politics and various research results show that there are two main factors that make ethnicity and religion interesting and appear (salient) to be used and influence in the political process. First, when ethnicity and religion are at stake. There is a kind of need to maintain or defend the identity of a group. Second, when the political process takes place competitively. It means that the political process causes identity group to face each other and no one is dominant, so it is not very clear who will be the winner since long ago.

Elections, including local elections, are political processes in which various factors such as identity are at stake. Just now how the actors involved in managing issues such as ethnicity and religion, are at stake.

According to Isin, Wood \& Wood (1999), in understanding the conception of the practice of citizenship, it must be associated with an understanding of the conception of identity. According to him, there are differences and similarities between the conception of identity and citizenship which cause problems when talking about both. There are many 
opinions about identity and citizenship, by being responsive to those represented. scientists agree that both are 'group This shows that there is a responsive markers'. Identity is a distinguishing relationship between those who represent marker from one group to another, while and those represented. Pitkin then offers citizenship is a marker of membership in a four views on the concept of political community. Although as a group representation, namely: first, formal marker, there are differences between the representation. Formal representation is two, namely the identity of carrying out defined as institutional/institutional socio-culture, and citizenship carrying a management that is carried out before the formal legal burden.

Meanwhile, according to Kristian representation and initiates its formation. Stokke from the chart previously explained, Second, descriptive representation. it asserts that the 4 types of partial Descriptive representation is a form of representation based on similarities or citizenship depend on one's status in similarities between representatives and relation to each of these dimensions. voters (or between those who vote and Stratified citizenship can also originate who are chosen). Third, symbolic from each of the four dimensions, namely representation. Symbolic representations through membership, various legal status, are the ways a representative stand for rights and participation. Next, Stokke defending his constituents or voters. explained that the nature of citizenship Fourth, substantive representation. politics, especially in the relationship Substantive representations, also called between redistribution politics (rights) and 'acting for' representations, are concepts recognition politics (membership which show that the activities carried out dimension), whereas political representation, as a dimension of injustice and citizenship politics.

\section{Political Representatives}

Women's representation in politics is important not only for women themselves but also for society as a whole. This political representation or representation, according to Pitkin (1967), is defined as acting based on the interests represented, by a representative on behalf of or for the interests they represent (Soeseno, 2013).

If we look at the concept of political representation conveyed by Pitkin above, basically it is not only a matter of quantity representation but more than that, namely quality representation carried out in a political institution. The concept of political representation which is almost the same was also conveyed by Phillips (1995). She explained the concepts of politics of 
Table 3. Comparison of the DPT with Male and Female Voters between the 2009 and 2019 Legislative Elections

\begin{tabular}{|c|c|c|c|c|c|c|}
\hline \multirow{2}{*}{ General Election } & \multicolumn{3}{|c|}{ List of Permanent Elections (DPT) } & \multicolumn{3}{|c|}{ Voter Political Participation } \\
\hline & Male/\% & Female/\% & Total & Male/\% & Female/\% & Total \\
\hline $\begin{array}{l}\text { Le } \\
\text { Ele }\end{array}$ & $\begin{array}{r}1.54 \\
(48\end{array}$ & $\begin{array}{c}1.609 .488 \\
(51.02)\end{array}$ & 3.155 .148 & $\begin{array}{c}1.047 .506 \\
(47.12)\end{array}$ & $\begin{array}{c}1.175 .733 \\
(52.88)\end{array}$ & 2.2 \\
\hline $\begin{array}{l}\text { Legislative } \\
\text { Election } 2019\end{array}$ & $\begin{array}{c}1.919 .174 \\
(49.43)\end{array}$ & $\begin{array}{c}1.963 .213 \\
(50.57)\end{array}$ & 3.882 .387 & $\begin{array}{c}1.379 .099 \\
(46.96)\end{array}$ & $\begin{array}{c}1.557 .620 \\
(53.04)\end{array}$ & 2.936 \\
\hline
\end{tabular}

ideas and politics of presence. According to Phillips (1995), politics of ideas is effective when there is politics of presence. In other words, quality of political ideas become effective in encompassing the interests of the community when voiced in the presence of people's representatives in political institutions. Likewise, when women's personal and group interests can be resolved if there are representatives of women in policy-making political institutions.

Suseno (2011) wrote that representation develops following various political changes taking place in the world both theoretically and on a practical level. Representations can simply be interpreted as presenting the absent. Political representations involving "elections" or elections as the main institutions in representative government. Meanwhile, according to Vieira and Runciman (2008) when talking about representation, there are three concepts that follow, first, pictorial representation, those who are chosen to represent must resemble those they represent. Second, theatrical representation, the elected representatives must interpret, speak and act for the parties they represent. Third, juridical representation, the elected representatives must act on behalf of the representatives they represent with mutual agreement and interests.

\section{Minangkabau Women}

The participation of Minangkabau women in the 2019 general election, which took place on April 17, was very high. The total number of women who had voting rights was 1,963,213 voters. The number of women who participated in voting in the people's representatives was more than $79.34 \%$ of women participated in the general election (see table 3).

Based on the above data, it can be seen how Minangkabau women had a high level of participation in voting in general elections. However, although there was a high participation of Minangkabau women, based on data collected, women who sit in the legislative seat of the province of West Sumatra, are still very few. It is not directly proportional to women's participation in 
voting with very high participation rates the legislature. Even though there is an (see table 4).

Affirmative Action policy, it does not help

The above table shows an increase of the number of women's representation in many legislative women candidates to win. the Provincial DPRD West Sumatra, which was $12.72 \%$ (7 elected women) in the 2009 election. However, it has decreased in 2019 to $6.15 \%$ (4 elected women). Even if it is seen from the number of voters in West Sumatra, it shows that women were more than men, while the election results obtained by women were less than men. The position of women to be involved in the political sphere, especially in politics, has been guaranteed by law with the $30 \%$ quota of women both in the 2009 and 2019 electoral laws.

In 2009, the political parties that succeeded in placing women in the legislature were Democrats (3), Golkar (1), Gerindra (1), and PAN (2). In 2019, political parties that succeeded in placing women in the legislature were Gerindra (2), Golkar (1) and PDIP (1). Based on data from both elections, the political parties that often elect women were Gerindra (2 people) and Golkar (2). The parties that elected women the most from both elections were PDIP, Golkar and Gerindra. This means that elected legislative members tend to shift, as well as their parties.

This phenomenon proves that it is still not easy for women to be elected easily in Based on data from the vote acquisition of women sitting in the legislature, there are still a few women in West Sumatra province who are able to compete for the legislative seats; even though women's participation in voting was very high. Such fact becomes an interesting point for the writers to see this phenomenon.

Based on the identity politics of Minangkabau women in adat, the treasure of the wisdom of the Minangkabau tradition, the relative authority is in the hands of elderly women (mothers and grandmothers) who act as controllers of power (von Benda-Beckmann, 2010; von Benda-Beckmann, 2012; von BendaBeckmann, 2013). In Minangkabau culture, the ancestors of the oldest women, if still alive, actually have a higher position than the mamak (head of the tribe). It is women who hold the inheritance, as the holder of the highest economic responsibility and at the same time as the controller of power in the nagari (village). Consequently, no important decision is made without her knowledge (Idris, 2017; Wiryomartono, 2014).

However, the fact shows that the number of Minangkabau women who 
Table 4. Comparison of election results, 2009 and 2019 in Women's Representation in the West Sumatra Provincial Regional People's Representative Assembly

\begin{tabular}{|c|l|c|c|}
\hline No. & Party & 2009 & 2019 \\
\hline 1 & Demokrat & 3 & - \\
\hline 2 & Golkar & 1 & 1 \\
\hline 3 & PDIP & - & 1 \\
\hline 4 & PKS & - & - \\
\hline 5 & PAN & - & - \\
\hline 6 & PBB & - & - \\
\hline 7 & PPP & 1 & - \\
\hline 8 & Gerindra & - & 2 \\
\hline 9 & Hanura & - & - \\
\hline 10 & Nasdem & $7(55)$ & $4(65)$ \\
\hline \multicolumn{2}{|c}{ Total } & $(12,72 \%)$ & $(6,15 \%)$ \\
\hline
\end{tabular}

Source: West Sumatra KPU, (processed).

occupy positions of political representation in West Sumatra is still very low. There is a gap between what is revealed culturally and the reality or practice, especially in the political sphere.

Moreover, the identity of Minangkabau women from religious perspective is seen as a social reproduction, culture becomes a view of life that is passed down from generation to generation. Therefore, the religious domain has a close relationship with the cultural domain even though they cannot be reduced to each other. This kind of fact also happened to the Minangkabau people, where adat (culture) and religion are inseparable.

Minangkabau people refer to culture as a custom or customary rule. Adat applies to various practices, including social relations, celebrations and kinship. The culture intended in Minangkabau are rules, values, norms based on Islam (adat basandi syara 'syar' basandi kitabullah) (Idris, 2017). Adat (culture) and religion have intertwined in Minangkabau society, and in turn will influence the practice of politics, including how to occupy, regulate and determine (limit) women's participation in politics.

\section{Matrilineal Culture Versus Patrilineal Culture}

In general, people recognize the Minangkabau community as an egalitarian and democratic society in the matrilineal cultural system, where the position of women and men is equal (Bonate, 2017). Therefore, it can be understood that in West Sumatra, the place where ethnic Minangkabau lives, contains a wide range of opportunities for women to obtain or gain positions in political leadership.

According to the prevailing tradition and already deeply rooted in the social life 
of Minangkabau, women are considered as the ultimate source of wisdom, also known in their customary expressions that women are: (a) Ambon Puro; key holder of the inheritance. Ambon puro is a kind of bag made of cloth to save puro money. Most of elderly Minangkabau women have puro. Therefore, in this case, women are the keepers of household welfare. Furthermore, women are described as (b) Unduang-unduang kemadinah, payuang panji kedalam surga. "Unduang-unduang ke Madinah" means the protector of Madinah (holiest city in Islam), the conveyor to the holy land, and "payung panji kedalam surga" means the guardian who directs the paths to heaven. In addition, women are also a reference figure, namely (c) kapai tampek batanyo kapulang tampek babarito, which literally means "a place to ask upon any departures, a place to tell stories once one arrives home". This expression means that all decisions that will be taken must be discussed with women first. This tradition is deeply entrenched in daily life.

The awareness of the importance of the role of women in politics is very much possessed by the Minangkabau community. This could be seen from the above description that the highest decisions are in the hands of women. However, it is different from men who have full power in Minangkabau, but again all forms of power must be discussed and agreed by Minangkabau women. Thus, matrilineal only means the maternal line, not the lineage of power.

On the other hand, over the years, patriarchy has placed men in the top hierarchy, while women have become number two. This is seen in the practice of the Hindu community. Since long time ago until now Minangkabau culture applies Matrileneal culture (Dewi et al., 2019; Long, 2016). However, patriarchal culture is still inherent in the lives of the people, this is what indicates that men are still in the top position. Most Indonesians generally adhere to the patriarchal system, so that the position of women in society is still seen as not more than men and men too always positioned first, superior and dominant in the community. Yusalia (2014), states that patriarchal culture refers to socio-cultural conditions that give the view that men are superior. With the intention that men are in the position of women so they can control women, culture like this grows in ancient societies and creates certain myths. Patriarchal culture also arises from physical differences between men and women.

Women's political participation is currently needed in an effort to integrate gender needs in various public policies (Yusalia, 2014). Women's participation is talking about how women access the political realm. Talking about how women 
"seize seats" in the realm of parliament which is still deeply controlled by patriarchal regimes and even the political sphere tends to be connoted as a patriarchal masculine realm. The assumption is that the low participation and substantive role of women in the political sphere is directly proportional to the realization of their potential to voice women's interests and rights (Kollo, Sumatra. 2017).

Women's participation in the political field must be supported in order to be able to implement capabilities possessed by women in the political field, with the aim of being able to prosper society in general. In patriarchal culture, it is clear that power and decision making are in the hands of men, so women are much marginalized.

\section{CONCLUSION}

In this case, identity and citizenship politics are an attempt to understand the relationship between these two concepts to the involvement of Minangkabau women in political participation and political representation in each election. Based on the conception of identity politics with citizenship in order to see Minangkabau women, in terms of identity politics Minangkabau women have 2 identities namely adat and religion as socio-cultural carriers, and yet Minangkabau women as citizenship carry a formal legal burden, still bound in patriarchal culture. In its implementation it is proven that in particular the very high political participation of Minangkabau women, both as holders of voting rights and as users of voting rights (political participation) will be able to influence representation in regional legislative bodies, especially in West According to Pitkin (1967), political representation is defined as acting based on the interests represented, by being responsive to those represented. Based on the study of Diarga Ardiansyah, that the practice of political representation in Indonesia has to do with the issue of women's political representation, where he explained that women's political representation based on the interests that influence the decisions taken. Based on the two opinions regarding women's political representation, it can be concluded that women's political representation has not reached the Pitkin and Diarga Ardiansyah thoughts, but it is still in the quantity or amount of political representation.

Therefore, it can be concluded that the low political representation of Minangkabau women in legislative institutions is not because of identity politics based on adat and religion, but 
because in the context of citizenship patriarchal culture is still rooted and dominates the life of the nation's politics.

\section{REFERENCES}

Ardiansa, D. (2017). Menghadirkan Kepentingan Perempuan dalam Representasi Politik di Indonesia. Jurnal Politik, 2(1), 71-99. Crossref | Google Scholar

Bernstein, M. (2005). Identity politics. Annu. Rev. Sociol., 31, 47-74. Crossref | Google Scholar

Bonate, L. J. (2017). Islam and matriliny along the Indian Ocean rim: Revisiting the old 'paradox' by comparing the Minangkabau, Kerala and coastal northern Mozambique. Journal of Southeast Asian Studies, 48(3), 436451. Crossref | Google Scholar

Dewi, S. F., Montessori, M., Saputra, R. A., Farsalena, S., Fatmariza, F., Febriani, R., \& Yulika, F. (2019). The Role of Culture in Cross-Cultural Marriage among Minangkabau Women. Journal of International Women's Studies, 20(9), 68-82. Google Scholar

Elfira, M. (2018). The Empress is Back on The Stage: Woman Leadership in Minangkabau Folklore. International Review of Humanities Studies, $1(2)$. Crossref | Google Scholar

Haboddin, M. (2012). Menguatnya Politik Identitas di Ranah Lokal. Jurnal Studi
Pemerintahan, 3(1). Crossref | Google Scholar

Hiariej, E., \& Stokke, K. (Eds.). (2017). Politics of citizenship in Indonesia. Yayasan Pustaka Obor Indonesia. Google Scholar

Idris, N. (2010). Perempuan Minangkabau dalam politik. Humaniora, 22(2), 164175. Crossref | Google Scholar

Idris, N. (2017). Perempuan Minangkabau dalam Metafora Kekuasaan, Yogyakarta: Pustaka Pelajar. Google Scholar

Isin, E. F., Wood, P. K., \& Wood, P. (1999). Citizenship and identity (Vol. 448). Sage. Google Scholar

Kollo, F. L. (2017). Budaya Patriarki dan Partisipasi Perempuan dalam Bidang Politik. 3rd National Conference of Citizenship. Universitas Ahmad Dahlan. Google Scholar

Kristianus, K. (2016). Politik dan Strategi Budaya Etnik dalam Pilkada Serentak di Kalimantan Barat. Politik Indonesia: Indonesian Political Science Review, 1(1), 87-101. Crossref | Google Scholar

Long, N. J. (2016). Caged in on the Outside. Moral Subjectivity, Selfhood, and Islam in Minangkabau, Indonesia, written by Gregory M. Simon. Journal of the Humanities and Social Sciences of Southeast Asia, 172(1), 146-149. Google Scholar 
Maclure, J. (2003). The politics of recognition at an impasse? Identity politics and democratic citizenship. Canadian Journal of Political Science, 36(1), 3-21. Crossref | Google Scholar

Marshall, T. $H_{.}, \quad \&$ Bottomore, T. (1992). Citizenship and social class (No. 323.6 M3). Google Scholar

Moleong, L. J. (2004). Metodologi

Penelitian Kualitatif, Bandung: PT. Remaja Rosdakarya. Google Scholar

Nasrudin, J., \& Nurdin, A. A. (2018). Politik identitas dan representasi politik (Studi kasus pada Pilkada DKI periode 2018-2022). Hanifiya: Jurnal Studi Agama-Agama, 1(1), 34-47. Crossref | Google Scholar

Pandiangan, L. V. (2017). Perempuan Politisi Minangkabau Dalam Dunia Politik: Studi Tentang Alasan Perempuan Memaknai Politik. Jurnal Politik Muda, 6(2), 148-155. Google Scholar

Phillips, A. (1995). The politics of presence. Clarendon Press. Google Scholar

Pitkin, H. F. (1967). Political representation. Representation and Electoral Systems: Canadian Perspectives, 73-90. Google Scholar Purvis, T., \& Hunt, A. (1999). Identity versus citizenship: Transformations in the discourses and practices of citizenship. Social \& Legal Studies, 8(4), 457-482. Crossref | Google Scholar

Sait, M. S. (2013). Women's Property Rights in Muslim Matrilineal Communities. J. Islamic St. Prac. Int'I L., 9, 1. Google Scholar

Samry, Wannofri., \& Omar, Rahilah. (2012). Gagasan dan Aktiviti Wartawan Wanita Minangkabau Pada Masa Kolonial Belanda. Jebat: Malaysian Journal of History, Politics \& Strategy, 39(2). Google Scholar

Snanfi, F. L., Darwin, M., Setiadi, S., \& Ikhwan, H. (2018). Identity Politics of Papuan Indigenous Ethnics in the Position Seizure Contestation: A Case Study of the OPD Structural Positions in the Governmental Bureaucracy in Papua. Politik Indonesia: Indonesian Political Science Review, 3(2), 196216. Crossref | Google Scholar Soeseno, N. (2013). Representasi Politik: Perkembangan dari Ajektiva ke Teori. Puskapol, Jakarta. Google Scholar Suseno, N. (2010). Kewarganegaraan: Tafsir, Tradisi dan Isu-Isu Kontemporer. Jakarta: FISIP UI. Google Scholar

Suseno, N. (2011). Kewarganegaraan dan Problema Perempuan di Indonesia diantara Persamaan, Pemeliharaan dan 
Perbedaan. Jurnal Studi Politik, 1(2). Google Scholar

Vieira, M. B., \& Runciman, D. (2008). budaya patriarki. Wardah, 15(2), 195201. Google Scholar

Representation. UK: Cambridge Polity

Press. Google Scholar

von Benda-Beckmann, F., \& von Benda-

Beckmann, K. (2010). Multiple embeddedness and systemic implications: struggles over natural resources in Minangkabau since the Reformasi. Asian Journal of Social Science, 38(2), 172-186. Crossref । Google Scholar

von Benda-Beckmann, F., \& von BendaBeckmann, K. (2012). Identity in dispute: law, religion, and identity in Minangkabau. Asian Ethnicity, 13(4), 341-358. Crossref | Google Scholar von Benda-Beckmann, F., \& von BendaBeckmann, K. (2013). Political and legal transformations of an Indonesian polity: the Nagari from colonisation to decentralisation. Cambridge University Press. Google Scholar

Wiryomartono, B. (2014). Ninik Mamak: Motherhood, Hegemony and Home in West Sumatra, Indonesia. In Perspectives on Traditional Settlements and Communities (pp. 113-131). Springer, Singapore. Crossref । Google Scholar

Yusalia, H. (2014). Pengarusutamaan gender (PUG) dalam tantangan 